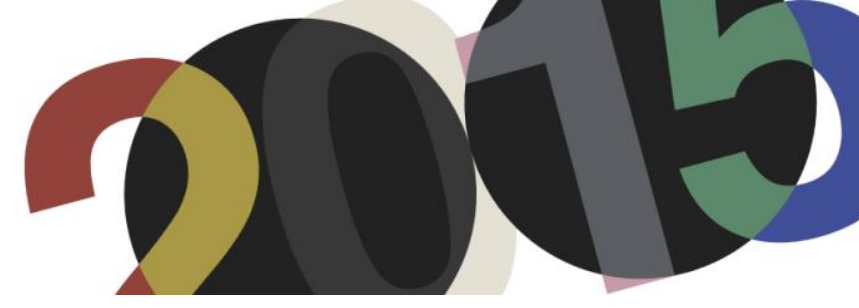

DOI: http://dx.doi.org/10.4995/LC2015.2015.723

\title{
Learning how to design architecture form the Villa Savoye design process
}

\author{
K. Vandenhende
}

KULeuven

\begin{abstract}
How to design architecture? And what makes a design process an interesting one? For non-experienced designers, it is difficult to understand typical aspects of exemplary design processes, like conflicting constraints, using mixed media, divergent thinking, working iteratively and in a non-lineair way, or integrating, many topics in one solution, balancing between a straightforward concept and ambiguïty, elaborating earlier concepts and learning from history. These characteristics were highlighted in various publications by several researchers during the past decades. And although the Villa Savoye was built before all that research, the extensive documentation of its design process by the Fondation Le Corbusier, makes it an excellent example to illustrate typical aspects of interesting design processes in a retroactive manner.
\end{abstract}

Keywords: Villa Savoye; design process; integrated;, iteratively; concept; ambiguity.

\section{Introduction and methodology}

Most architecture students, at the beginning of their studies, have no experience at all in designing. It might help to explain them the typical aspects of interesting design processes, explored by many researches since the second half of the twentieth century. But it is difficult for students to understand these complexities without an interesting example.

Thanks to the 'Fondation Le Corbusier', the different phases of the design of the Villa Savoye are well documented. Le Corbusier's drawings and the story of the conception of the Villa Savoye, can thereby help to make the design process itself comprehensible.

This paper gives an overview of important aspects of design processes, highlighted by several authors during the past decades, each of these characteristics illustrated with the design process of the Villa Savoye.

\section{Typical aspects of the design process}

\subsection{Design proclems deal with many, often conflicting, constraints}

Architectural design is a form of problem solving in which designers have to deal with a lot of requirements. These can be very diverse, and they can be in conflict with each other. They range from constraints concerning the distribution of towns to constraints concerning the distribution of light fixtures ${ }^{1}$. In the case of the design of an Indian Village for example, Christopher Alexander stated that he worked with up to 140 requirements $^{2}$.

\footnotetext{
${ }^{1}$ Alexander Christopher: A Pattern Language. New York: Oxford University Press, 1977

2 Jones J.C.: Design Methods. New York: John Wiley \& Sons, 1992
} 
When Le Corbusier was approached with the commission for the Villa Savoye in 1928, he had almost carte blanche and could set his own limits. At that time, he had reached a stage of extreme clarity in the formulation of his vocabulary, so he was well-armed with a priori ideas and constraints of his own, like purity of form on the one hand and the ideas summarized in his 'Les 5 points d'une architecture nouvelle' on the other: the pilotis, the roof garden, the free plan, the elongated window and the free façade ${ }^{3}$. All these aspects were part of the first project for the Villa Savoye, presented in October 10 1928, but came in conflict with economic reality. The first design was to too expensive and Le Corbusier and Pierre Jeanneret would have to rework the scheme in a way to meet all constraints.

\subsection{Mixed media}

In a drawing of that first design (1), Le Corbusier combined the three floor plans together with sketches that showed the interior and exterior of the villa.

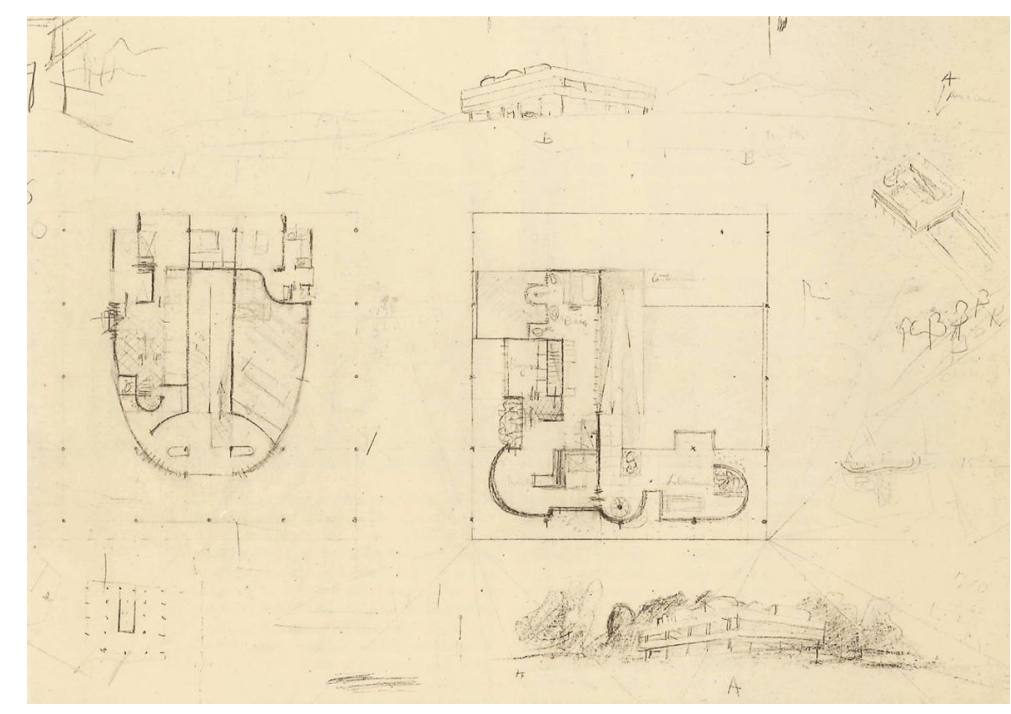

1. Part of the drawing of the first design, September 1928 (FLC 19583 OFLC-ADAGP)

Many theorists and architects wrote about this mixing of design media. Caruso ${ }^{4}$ stated that the diversity of constraints is often made visible in drawings that combine different media: schemes of overall concepts, perspective views and solutions for details. Each of these media medium or form of representation is used for a particular facet of the process. Lawson ${ }^{5}$ agreed that in architectural practices, design drawings are often overlaid and mixed together. Two-dimensional plans or sections can be seen with sketches and more diagrammatic marks all on the same piece of paper in what appears a confusing jumble. Neutelings ${ }^{6}$ stated that designers rely on various modes of representation to work their way through the design process, and the skill needed to design has a direct relationship with the various media available during the design process. The combination of text, image, sketch and/or draft can provoke among Heylighen ${ }^{7}$ new associations, which keep the design process going. An overview of all representations supports the architect in combining the different kinds of information.

\footnotetext{
${ }^{3}$ Curtis William J.R.: Le Corbusier Ideas and Forms. Oxford: Phaidon, 1986. pp. 93-99.

${ }^{4}$ Caruso Adam: "Over maquettes en beelden" in Oase: "Models/Maquettes". № 84. 2011, p.138-139.

${ }^{5}$ Lawson Bryan: Design in Mind. Oxford: Reed, 1997

${ }^{6}$ Neutelings Willem-Jan; Riedijk Michiel: At Work. Rotterdam: 010, 2005

${ }^{7}$ Heylighen Ann; Segers Nicole: "An architectural Shift+F7" in EAAE Transactions on Architectural Education. N 14. Montreal: EAAE, 2004. p.134-143.
} 


\subsection{Divergent Thinking}

The importance of generating variations or alternatives cannot be overestimated. According to Liu $^{8}$, designers have to test several alternatives, before finding a possible solution. They have to generate a wide range of concepts to prevent overlooking valuable ones. They have to evaluate and select these soon enough to restrict their number from getting too large to allow meaningful consideration. During the conceptual stage, in the formulation of McGown', the number of what are called 'lateral' transformations shouldn't be exaggerated. In a lateral transformation, as Goel $^{10}$ specified, movement is from one idea to a different idea. In a vertical transformation, movement is from one idea to a more detailed and exacting version of the same idea. Good design is a result of balance between lateral and vertical transformation. It is a result of a balance between divergent and convergent thinking. As written by Marples ${ }^{11}$, the nature of the problem can only be found by examining it through proposed solutions, and it seems likely that its examination through just one proposal leads to a very biased view. It seems probable that at least two radically different solutions need to be attempted in order to obtain a clear picture of the 'real nature' of the problem through comparisons of subproblems. Therefore, Lawson ${ }^{12}$ stated that it might be perhaps better for designers to use divergent thinking in excess rather than too sparingly.

How could the first project of the villa Savoye be made less expensive? As Benton ${ }^{13}$ analysed, the first project for this villa was based on a rigid 5-by-5-meter grid, and moreover, it used the dimension of the turning circle of a large car and the space required to bring a gently sloping ramp up through the house without dividing the plan in two. Just trying to reduce the dimensions a bit in all directions, would have made it impossible to maintain those important features. Therefore, Le Corbusier and Pierre Jeanneret tried in November 1928 several alternatives not maintaining all these typical characteristics of the first concept ${ }^{14}$. On November 26 , they made a completely new design; a juxtaposition of vertical volumes incorporating a vertical staircase block with a 'pan de verre' window (2).

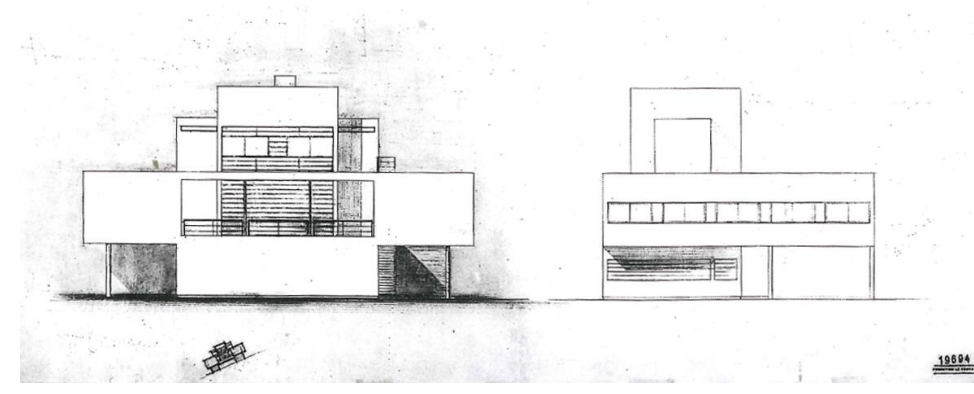

2. Façade of the scheme of November 26 (FLC 19694 OFLC-ADAGP)

\footnotetext{
${ }^{8}$ Liu Y.C.; Blight T.; Chakrabarti A.: "Towards an 'ideal' approach for concept generation” in Design Studies. No 4. 2003

${ }^{9}$ McGown Alistair: "Visible ideas: information patterns of conceptual sketch activity" in Design Studies. No 4. 1998

${ }^{10}$ Goel V.: Sketches of Thought. Cambridge: MIT Press, 1995

${ }^{11}$ Marples D.: The decisions of engineering design. London: Institute of Engineering Designers, 1960

${ }^{12}$ Lawson Bryan: How Designers Think. Oxford: The Architectural Press, 1980

${ }^{13}$ Benton Tim: Le Corbusier Architect of the Century. London: Arts Council of Great Britain, 1987

${ }^{14}$ Quetglas Joseph: Les heures Claires. Barcelona: Centre d'Investigacions estètiques, 2009
} 


\subsection{Iterative process}

After two months of research and several proposals, the architects still weren't satisfied with the newly developed concepts and looked back to their first drawings. However, the second and third projects were not useless at all. These alternative designs did help them to find saving solutions: by increasing the density of parts on the ground floor and the first floor, by reducing the terrace to a solarium, and by diminishing the range between posts. The new project of 21 December 1928, was in fact an adaptation of the first one, and costed much less $^{15}$.

About this iterative process is also written by researchers. Levin ${ }^{16}$ said that with a first concept, it's almost impossible to propose an idea that meets all preconditions at once. Eventually, as Lawson ${ }^{17}$ stated, unless the design proves totally successful, one of two things happen to halt this phase. Either the general form of the solution reveals itself incapable of solving enough problems, or so many modifications have to be made that the idea behind the solution is lost and abandonded. In either case the designer is likely to choose the revolutionary step of starting a completely new train of thought. Ching ${ }^{18}$ noted that while the design process is typically presented as a linear series of steps, it is more truly a cyclical, iterative sequence of careful analysis of available information; intuitive synthesis of insights, and critical evaluation of possible solutions. An iterative process that is repeated until a successful fit between what exists and what is desired is achieved. The design process can be compressed into a short, intense period of time or extend over several months or even years, depending on the urgency or complexity of the design problem. Design can also be an untidy process in which moments of confusion are followed by instances of exquisite clarity, interspersed with periods of quiet reflection. Designing is in fact searching without really knowing what to look for ${ }^{19}$.

\subsection{Integrated architecture: merge and blend.}

In their final design, Le Corbusier and Pierre Jeanneret seemed to return to their first project, with only minor modifications. But in fact, in that last project, they managed to combine qualities of several of the previous designs, thereby adding the richness and complexity as Benton ${ }^{20}$ noticed. The contrast between horizontal and vertical, almost absent from the first project, but a main feature in the scheme of 26-27 November, was reintroduced in the final scheme in the form of the spiral staircase. Also the pan de verre modified the first project and made it possible to see down into the entrance hall and out onto the terrace as you move up or down the ramp.

From research about architectural design, we learn that combining multiple qualities in one solution gives satisfactory results. Jones ${ }^{21}$ clarified that ideas encompassing multiple topics are also called integrated or also composite. For architect Peter Zumthor ${ }^{22}$, architecture is at its most beautiful when things have come into their own -- when they are coherent. That is when everything refers to everything else, and it is impossible to remove a single thing without destroying the whole. Place, use, and form. The form reflects the place, the place is just

\footnotetext{
${ }^{15}$ Ragot Gilles; Dion Mathilde: Le Corbusier en France. Paris: Le Moniteur, 1997

${ }^{16}$ Levin P.H.: Decision making in urban design. Herts: Garston, 1966

${ }^{17}$ Lawson Bryan: How Designers Think. Oxford: The Architectural Press, 1980

${ }^{18}$ Ching Francis D.K.; Eckler James F.: Introduction to Architecture. New York: John Wiley \& Sons, 2012

${ }^{19}$ Neutelings Willem-Jan; Riedijk Michiel: At Work. Rotterdam: 010, 2005

${ }^{20}$ Benton Tim: The Villas of Le Corbusier and Pierre Jeanneret 1920-1930. Basel: Birkhauser, 2007, p. 183-201.

${ }^{21}$ Jones J.C.: Design Methods. New York: John Wiley \& Sons, 1992

${ }^{22}$ Zumthor Peter: Atmospheres: Architectural Environments - Surrounding Objects. Basel: Birkhauser, 2006
} 
so, and the use reflects this and that. Architectural qualities of the design must merge and blend with the constructional and formal structure of the finished building. Form and construction, appearance and function are then no longer separate. They belong together and form a whole.

Benton $^{23}$ noted that the use for a standard window in the Villa Savoye can be read on numerous levels. First of all, the 'fenêtre en longueur' was made possible by the concrete structure and as such it served as an expression of that structure. Secondly, it was also an interior solution, being the most efficient way to distribute light. Thirdly, the 'fenêtre en longueur' was also a storage solution, whereby underneath the long windows built-in cupboards allowed for storage and concealed distribution channels for services. And finally, it was a technical solution, of which the architects tried to patent the sliding window.

Another example of integrated architecture in the Villa Savoye comes with the question of channelling and containing a route inside a regular volume, and linking that route to spaces of different size and intensity. Symmetry and asymmetry were both relevant, as were closure and transparency, a disciplining grid and fragmentation of that grid, the taut planes of the box and the sensuous spaces created by curves. All this resulted in a new combination for the 'Five Points'. At the end of the 1920s he drew a series of sketches comparing the house of the Maison La Roche/Jeanneret, to the final project for the Villa Baizeau at Carthage, and to the Villa Stein at Garches. The Villa Savoye fused together the asymmetry, spatial drama and promenade architecturale of the first, with the skeletal character of the second, and the geometrical clarity of the third (3). It combined the square, the grid, the axis, the frontal plane and a turbulent drama of interior and exterior spaces, volumes and surfaces; and it managed to play these together while maintaining unity, hierarchy and an appropriate level of $\operatorname{detail}^{24}$.

1

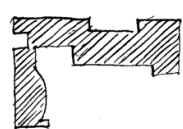

2

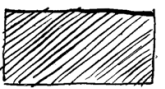

3

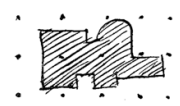

4

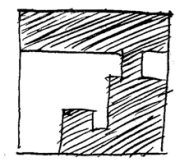

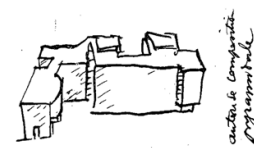
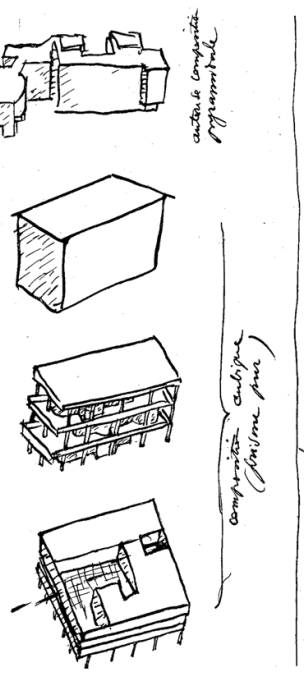

3. Sketches as published in Le Corbusier Pierre Jeanneret, Oeuvre Complète, volume 1.

\footnotetext{
${ }^{23}$ Benton Tim: Le Corbusier Architect of the Century. London: Arts Council of Great Britain, 1987

${ }^{24}$ Curtis William J.R.: Le Corbusier Ideas and Forms. Oxford: Phaidon, 1986. pp. 93-99.
} 


\subsection{Balancing a straightforward concept with ambiguïty.}

Winters $^{25}$ explained that variety or diversity is an important design consideration because "too much" visual activity may cause a chaotic effect. On the other hand, no variety or diversity results in monotony. The architectural designer must walk the tight rope between chaos and boredom to create a building or space of enticing interest. A balancing of complexity or detail on the one hand, and simplicity or plainness on the other, is necessary. When a building uses too many elements we say it is 'busy'. When a building uses no variety in elements we say it is uninteresting. The architect must have a balance of simplicity and restful visual areas with complex, more active forms. Venturi ${ }^{26}$ liked elements which are hybrid rather than "pure," compromising rather than "clean," distorted rather than "straightforward," ambiguous rather than "articulated," perverse as well as impersonal, boring as well as "interesting," conventional rather than "designed," accommodating rather than excluding, redundant rather than simple, vestigial as well as innovating, inconsistent and equivocal rather than direct and clear. He prefered messy vitality over obvious unity.

The architect Fujimoto ${ }^{27}$ declared that he wanted to make architecture that even a child can draw. A desire for lucidity. However, at the same time, he wanted this lucid architecture to contain an incomprehensible diversity. A place containing both the lucidity of the solution at the moment it appeared, and the experience of a profound diversity throughout.

We can find an example of this balance between concept and detail in the strip window bordering the terrace in the south façade of the Villa Savoye. This window was so broad that it had to be reinforced by two baby pilotis linking horizontal stiffeners. Seen from the outside these delicate cylinders hover in an ambiguous position (4). They seem part of the façade, which they are, but their diminutive size in comparison with the normal pilotis also forces a perspectival reading so that they are read simultaneously well within the building ${ }^{28}$.

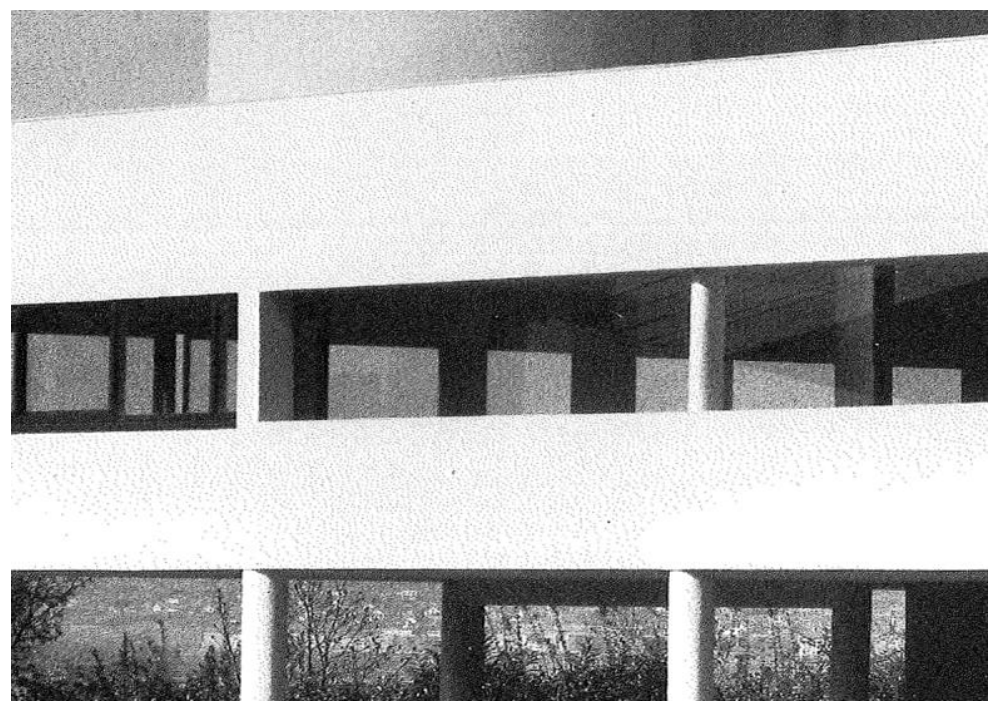

4. Photo of south façade showing the strip window pilotis having an ambiguous position.

\footnotetext{
${ }^{25}$ Winters Nathan B.: Architecture is Elementary. Salt Lake City: Gibbs M. Smith, 1986. p. 136.

${ }^{26}$ Venturi Robert: Complexity and Contradiction in Architecture. New York: Museum of Modern Art, 1966

${ }^{27}$ Fujimoto Sou: "Sou Fujimoto" in 2G. N50. 2009

${ }^{28}$ Curtis William J.R.: Le Corbusier Ideas and Forms. Oxford: Phaidon, 1986. pp. 93-99.
} 


\subsection{Elaborating earlier concepts.}

Many typical elements of the Villa Savoye, had all been worked out in earlier buildings. For example, already in 1925, Le Corbusier had developed a project which combined the stilt, the cube, and the sculptured roof, namely for the Villa Meyer, a project that was never realized ${ }^{29}$.

And Benton shows that the key features of the Villa Savoye design have emerged form the early design stages of the Villa Baizeau in Tunis. A house where Le Corbusier worked on when the Poissy project was at least still six months away ${ }^{30}(5)$.

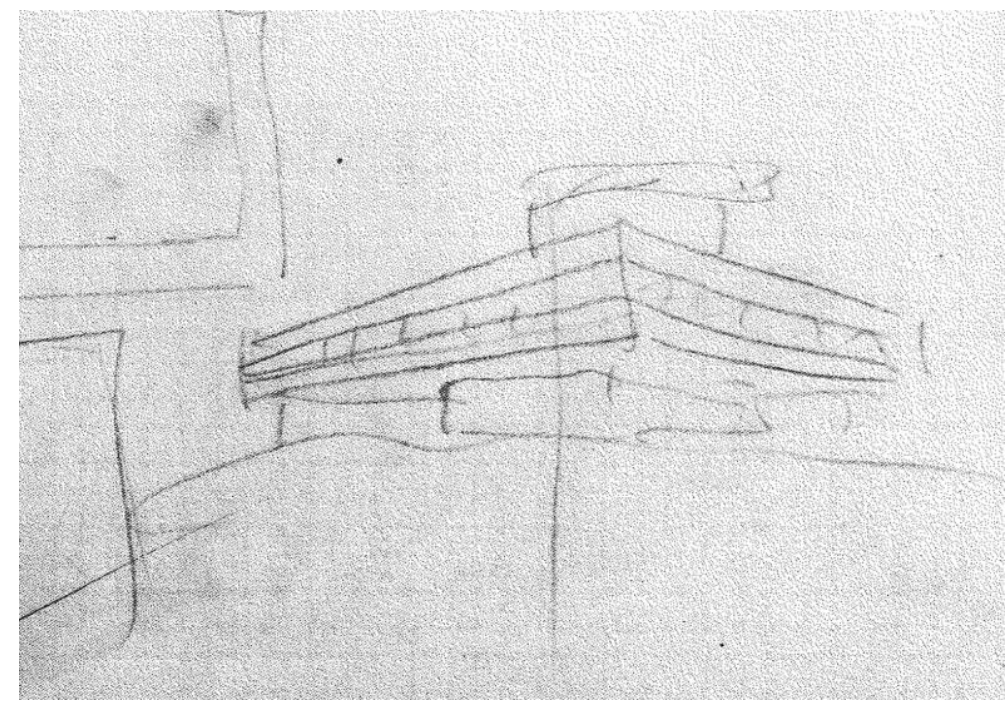

5. Part of sketch for the Villa Baizeau (FLC 24983 OFLC-ADAGP)

Architect Fujimoto ${ }^{31}$ stated that through heaps of models and by reusing, restacking and rethinking this heaps of models, they can generate a new model. These trashes and ruins give them inspiration to create something new. Being surrounded by models is important to get inspiration from different projects. This continuity of making and reusing models leads to evolution and eventually to new designs. Architect Ingels ${ }^{32}$ agreed that they also often sit in a design meeting and discover that there is this great idea, but that doesn't really work in that context. But for another client in another culture, it could really be the right answer to a different question. So as a result, they never throw anything out. They keep their office almost like an archive of architectural biodiversity.

\subsection{Learn from history.}

Starting from the existing to invent the new will thereby automatically facilitate cultural continuity. According to Caruso ${ }^{33}$, we are now working in a time that conspires to undervalue and dull our sensitivity to what has come before. Or as Ortega y Gasset ${ }^{34}$ mentioned that we cannot start afresh; that we must make use of what people have done before us. If we want to make progress, and this means that we must stand on the shoulders of our

${ }^{29}$ Benton Tim: The Villas of Le Corbusier and Pierre Jeanneret 1920-1930. Basel: Birkhauser, 2007, pp. 183-201.

${ }^{30}$ Benton Tim: "Villa Savoye and the Architect's Practice" in Allen Brooks H. (Ed.): Le Corbusier. Princeton: Princeton University Press, 1987. Pp. 83-105.

${ }^{31}$ Fujimoto Sou: "Understanding abiguous spaces" in Architecture as a craft. Nijmegen: Sun, 2011 p. 161.

${ }^{32}$ Ingels Bjarke: "3 warp-speed architecture tales" on www.TED.com, 2009

${ }^{33}$ Caruso Adam: Gardens of Experience, Amsterdam: Sun, 2010

${ }^{34}$ Rowe C. and Koetter F. : Collage Cit., Cambridge: MIT Press, 1978, p.86. 
predecessors, we must carry on a certain tradition. De Vylder ${ }^{35}$ stated that an architect should not always invent completely new concepts, but can start from an existing situation and bring that up to date. This will have the advantage of carrying the old in it. Part of the quality of the new lies in its comparison with the old. Or, as Perec $^{36}$ formulated for art paintings that a considerable number of, if not all, paintings only acquire their true significance in relation to the earlier works that are found in them, either simply reproduced whole or in part, or in a much more allusive manner, encrypted. Similarly, Geers ${ }^{37}$ wrote for architecture that the architect's project deals indirectly with everything that has happened before, both in the field of architecture and in the world. Architecture without acknowledging history is impossible. The project is not about inventions in order to bring something new into existence, but about formulating intentions to reassemble things already known in another way. In today's world, too much emphasis is put on the new, the fresh and the frenzy. Architecture is neither new nor old, architecture is always contemporary. Every new architecture reassembles chosen elements of a found reality.

Le Corbusier made several travels to study past architecture. In the villa Savoye, he was inspired by the earth ramps of Middle Eastern architecture for his promenade architectural. Among Le Corbusier, only on foot, in movement, can you see the developing articulation of the architecture ${ }^{38}$.

\section{Conclusion}

The making of the project for the Villa Savoye, seems to include all aspects of typical interesting design processes. As a frequently published that can also be visited and experienced in reality, it can help to explain the complexity of designing and make all these aspects of it more comprehensible.

\section{Bibliography/references}

Alexander Christopher: A Pattern Language. New York: Oxford University Press, 1977.

Benton Tim: Le Corbusier Architect of the Century. London: Arts Council of Great Britain, 1987.

Benton Tim: "Villa Savoye and the Architect's Practice" in Allen Brooks H. (Ed.): Le Corbusier. Princeton: Princeton University Press, 1987.

Benton Tim: The Villas of Le Corbusier and Pierre Jeanneret 1920-1930. Basel: Birkhauser, 2007.

Caruso Adam: Gardens of Experience, Amsterdam: Sun, 2010.

Caruso Adam: "Over maquettes en beelden" in Oase: "Models/Maquettes". № 84. 2011.

Ching Francis D.K.; Eckler James F.: Introduction to Architecture. New York: John Wiley \& Sons, 2012.

Curtis William J.R.: Le Corbusier Ideas and Forms. Oxford: Phaidon, 1986.

De Vylder J.: "Als een tekening” in 1 boek 2. Antwerpen: De Singel, 2011.

Jones J.C.: Design Methods. New York: John Wiley \& Sons, 1992.

Fujimoto Sou: "Sou Fujimoto" in 2G. N50. 2009.

\footnotetext{
${ }^{35}$ De Vylder J.: “Als een tekening” in 1 boek 2. Antwerpen: De Singel, 2011

${ }^{36}$ Perec G.: Le Cabinet d'amateur, La librairie du XXIème siècle ,1994

37 Geers K.: "Crafting architecture. In search of the architect's project" in Riedijk M. (Ed.) Architecture as a craft, Amsterdam: Sun, 2011

${ }^{38}$ Benton Tim: The Villas of Le Corbusier and Pierre Jeanneret 1920-1930. Basel: Birkhauser, 2007, pp. 183-201.
} 
Fujimoto Sou: "Understanding abiguous spaces” in Architecture as a craft. Nijmegen: Sun, 2011.

Geers K.: "Crafting architecture. In search of the architect's project" in Riedijk M. (Ed.) Architecture as a craft, Amsterdam: Sun, 2011.

Goel V.: Sketches of Thought. Cambridge: MIT Press, 1995.

Heylighen Ann; Segers Nicole: "An architectural Shift+F7" in EAAE Transactions on Architectural Education. $\mathrm{N}^{\mathrm{o}}$ 14. Montreal: EAAE, 2004.

Ingels Bjarke: "3 warp-speed architecture tales" on www.TED.com, 2009.

Jones J.C.: Design Methods. New York: John Wiley \& Sons, 1992.

Lawson Bryan: How Designers Think. Oxford: The Architectural Press, 1980.

Lawson Bryan: Design in Mind. Oxford: Reed, 1997.

Levin P.H.: Decision making in urban design. Herts: Garston, 1966.

Liu Y.C.; Blight T.; Chakrabarti A.: “Towards an 'ideal' approach for concept generation" in Design Studies. N 4. 2003.

Marples D.: The decisions of engineering design. London: Institute of Engineering Designers, 1960.

McGown Alistair: "Visible ideas: information patterns of conceptual sketch activity" in Design Studies. № 4. 1998.

Neutelings Willem-Jan; Riedijk Michiel: At Work. Rotterdam: 010, 2005.

Perec G.: Le Cabinet d'amateur, La librairie du XXIème siècle ,1994.

Quetglas Joseph: Les heures Claires. Barcelona: Centre d'Investigacions estètiques, 2009.

Ragot Gilles; Dion Mathilde: Le Corbusier en France. Paris: Le Moniteur, 1997.

Rowe C. and Koetter F. : Collage Cit., Cambridge: MIT Press, 1978.

Venturi Robert: Complexity and Contradiction in Architecture. New York: Museum of Modern Art, 1966

Winters Nathan B.: Architecture is Elementary. Salt Lake City: Gibbs M. Smith, 1986.

Zumthor Peter: Atmospheres: Architectural Environments - Surrounding Objects. Basel: Birkhauser, 2006. 